\title{
Cultural and Creative Industries: Is the 'Giant of Africa' Relevant in the Global Sphere?
}

\author{
Emmanuel Ezimako Nzeaka ${ }^{1}$ Beryl Annette Ehondor ${ }^{2 *}$ Kabir Matazu Ashiru $^{3}$ \\ 1,2,3 School of Media \& Communication, Pan-Atlantic University, Ibeju-Lekki, Lagos, Nigeria \\ *E-mail of the corresponding author: *beryl.ehondor@pau.edu.ng
}

\begin{abstract}
Globalization is now linked to economic advancement; the position of Nigeria in this regard through the creative and cultural industries is not in doubt. This paper attempted to create awareness on the place of Nigeria in the global creative and cultural industries. It is of the essence to create consciousness in this neglected area by the government and entrepreneurs alike, hence the contributions in these sectors of economic development of the country go unrecognized. Thus, this paper did a study of the position of Nigeria music and film industries in the planetary space and contributions to the national economy. It was observed that Nigeria occupies an enviable location in the global index in these areas, though there are no clear policies in these lucrative fields. Regardless of the neglect, the creative and cultural industries have managed to fill a position in the world through the individual persistence of the practitioners. This study created awareness on the carelessness of that sector and the need for all to pay attention to enable Nigeria to sustain her position in this ever-expanding and lucrative sector.
\end{abstract}

Keywords: Globalization; entrepreneurs; cultural creative industries

DOI: $10.7176 / \mathrm{JCSD} / 63-06$

Publication date: February $28^{\text {th }} 2021$

\section{Introduction}

In November 2017, the Minister for Information Mr Lai Mohammed in the fourth edition of the Fashion Art Fusion Show held in Lagos Nigeria, informed the audience that government was ready to encourage individuals to develop creative industries because it is capable of boosting the country's foreign exchange and internally generated revenue (IGR) (Magaji, 2018). In Madrid Spain in January 2020 in was declared that the Creative Industry is the fastest growing segment of the Nigerian economy in terms of business opportunities, job generation, earnings as well as entertainment.(Vanguardngr.com,2020)This news is very relevant because for a very long time the government did not pay attention to the hitherto neglected creative and cultural sector, but now officially recognized that sector as the driver of the economy apart from the oil which has been the mainstay of the Nigerian economy. Again, it seems to be a major government policy statement on that sector recently. The major study of the creative and cultural industry in Nigeria and what looks like a major document which mapped the industry was carried out in November 2013 by the British Council, Lagos (Dandaura, 2013). This mention by the government is very important because it has given credibility to the relevance to the recognition of the sector as a major player in the global trade. Nigeria has engaged in trade and business with many countries in the past from the export of cash crops in the 1950s to and petroleum products since the 1970s. These exports have improved rapidly and provided Nigeria with the much needed foreign exchange for imports. Other sectors also supported the economy and sustained export. This has made Nigeria visible in the comity of nations. The contributions of cultural and creative industries have never been acknowledged, as a contributor to the growth of the national economy. However, to observers, it seems that this unrecognized informal sector is developing rapidly to the extent that it would be a potent force in growing the economy if it is given the rightful place by the government as the products of that sector are becoming more sophisticated by world standard. To buttress this fact (Yahya,2020), a UNDP representative in Nigeria, stated in a workshop that Nigeria is a notable contributor to Africa's arts, culture and entertainment scenes, and its entertainment and music industry that emerged in the early 90 s is the fastest growing in the world, competing closely with America and India for the global market share. The Nigeria film industry (Nollywood), employs more than 1 million people - making it the second largest employer after agriculture. In 2016 the Nigeria film industry contributed 2.3\% (NGN239billion) to Nigeria's Gross Domestic Product (GDP), and is considered a priority sector in the Economic Recovery and Growth Plan of the Federal Government with expected export revenue of \$1billion by 2020.(para.2)

Consequent on the valuable export potential, products like arts and crafts have been unofficially exported to many African countries and the rest of the world through unofficial channels (Torres \& Seters, 2016). Their contributions to the growth of the national gross domestic product, GDP pass unacknowledged by economists and the 
government. For more elucidation of this reality, Nigeria film, fashion, music, food, and craft products are popular in Europe, the United States and the rest of the world, not to talk of its base in Africa, where they are household names The presence of Nigeria is documented in world fashion music and film centres in Paris, Milan, London and New York and in many African countries where they display their creativity and culture. For example, the Nigerian film industry is ranked third in the world in terms of film production. In 2015, it was ranked the second after Hollywood and some Nigerian movies are connected to Netflix for the world audience (Bright, 2015). The Nigerian creative and cultural industries are broad and humongous and the government and businessmen are yet to tap into this money-spinner. According to Eleanya (2020), Herbert Wigwe the CEO of Access Bank Nigeria recently pointed out that the creative industry comprising of the advertising, architecture, the arts and antiques market, crafts, design, designer fashion, film, interactive leisure software, music, performing arts, publishing, software, television, and radio can bridge the unemployment gap in Nigeria if commercial banks in the country are much more receptive to financing them (para.1). This sector of the growth is neglected, however if the government taps into it, it would contribute immensely to the development of the economy.

This paper with due consideration will narrow down to the film and music industry by strenuously looking at the current situation as regards their rating and situation when measured against the universal standard and the current reality through the lens of globalization. This means the paper will pay very close attention to the development, motivation and the issues these sectors have encountered. Also to be looked into will be the consideration of how to improve this sector to ameliorate these challenges and usher it to the world stage as the main driver of the Nigerian economy.

\subsection{What is Globalization?}

In the past decade, the concept of globalization has been used widely in economic, political, and cultural, it has almost encroached into all aspects of human development. It has become a buzzword, we are consistently reminded at every turn that the world is becoming a "global village", that this is the epoch of the shrinking of the social space and culture in all ramifications of life. All is being shrunk into a third space due to globalization (Lefebvre,1991: Soja,1999; Giddens,2018). Life no longer depends on historical conditions but has moved to the level of reduction of time, space and culture they are creating a novel third culture which agglomerates all our endeavours. However, the concept of globalization is not a new idea, it is as old as humans have lived on this planet and not new as people have been made to accept, what is happening is just an unprecedented consciousness of that concept (Rourke \& Williams,2002; Sheffield et al,2013; Northrop n.d). It started with the first exchange of goods, services , and communications man families, communities, states and nations in prehistory. From the Dutch and British seafarers who in the 16th century, scavenged the West African coastline for exchange of goods, to the internal trans- Saharan trade routes to the obnoxious triangular slave trade between Africa America and Europe were the purveyors of globalization.

Globalization, as we interpret it today, is just an acceleration of a former engagement between people and cultures, it has taken a faster dimension. In modern times it can be defined as the growth and development of the size of the social system which has made our social system complex due to the connection of the past, present and the future, which resulted in the shrinking of the economic, cultural, social-historical and religious spaces (Sheffield et al n.d). While some see it as putting the world in a global trap to be exploited by increasing disproportion and destabilization of the ability of the states to handle social challenges (O'Rourke et al,2002). Ordinarily, it can be seen as the rapid enlargement of all types of global arrangement, a convergence of human action that endures integration of socio-political ethos which can be determined by section, streams, business tradition, academic culture, secularism and religious culture (Northrop,n.d).In summary, it can be understood as the development of a worldwide influence put on socio-economic systems that are global in coverage. It assumes a multi-dimensional approach, thereby engendering conflict between different dimensions because it endeavours to subsume the developing economic structures in the pretext of accommodation (Abubakar, 2018). One strand runs in these attempts to define globalization, though they have different ideological approaches, they all come to an understanding that globalization has become unprecedented recently, especially with the advent of the internet and the new media.

In all, goods and services can be sent to any part of the world without the sender moving physically from different parts of the world in real-time. All these simply show that the world is indeed contracted due to the impact of globalization, which has resulted in the collapse of culture due to the coalescing of diverse traditions. This, in turn, provides a third culture that is insulated from any local influence. It should be noted that this third culture has been accelerated by the internet which has redefined the notion of space. The various definitions agree that the there is 
a steady decline of culture and in its place an acceptance of a universal application of the ways of life where society has evolved a multi-culture and an agglomerated by diverse economies into a universal vortex of production and distribution of services. It is within this notion of globalization that the paper will locate the concept of cultural and creative industries and understudy Nigeria's part in the universal arena.

\subsubsection{The Understanding of Creative and Cultural industries and the Impact in Global Economy}

The definition of creative and cultural industries (subsequently to be referred to as CCI) has attracted a lot of inconsistencies according to ideologies and regions. Critics have not been able to come to terms with a definite definition that will be universally accepted. Any attempt to define it has been fraught with the discrepancy, exclusiveness and provincial bias, thereby creating terminological irregularities (Hesmondhalgh,2008; Garnham,2005; Galloway\&O'Connor, 1999). Most definitions do not have a common ground and seem to contradict one another because they could not find a common agreement. However, an attempt was made by the UK government under Tony Blair administration in 1988 through a Department of culture media and sports (DCMS) to chart a definition as "those activities which have their origin in individual creativity, skill and talent and which have the potential for wealth and job creation through the generation and exploitation of intellectual property"(Galloway \& Dunlop,2007)Because of the government perceived relevance of the creative industry in the UK, it established a committee to identify the areas in the creative industry that the labour government will pay attention to help develop the economy. This committee identified areas like music, fashion, software , perfumery, arts, publishing, architecture, antique market and fashion as a very lucrative area that can buoy the economy(Creative Edge,2013).In as much as the paper will work with the definition of DCMS, it will also incorporate the definitions of the Orange Economy of the Americas and the Africa Nairobi Declaration creative and cultural industries. As it will broaden the scope of the definition and incorporate the elements of creativity and culture that were not indicated in the DCMS definition, like the inclusion of gastronomy, ancestral places, carnivals, libraries and jewellery ( Valdivieso,2016).As a result, the terms cultural and creative industry will be used concurrently and the two terms combined and shortened as previously stated, for the ease of understanding.

The CCI has evolved tremendously in the past years and contributed significantly to the global GDP. The impact is the world economy cannot be undervalued. According to the result of the mapping done in the UK in 2008 by the DCMS under Tony Blair's government, the CCI is a major contributor to the national economy and very important employer of labour indirectly (Higgs, 2008), engaging people in the critical sectors of the economy. Also, the Danish Enterprise and Construction Authority conducted a mapping of the country in 2001 and found out that and found out a similar strand in the economic structure of the country, that of the employment of people in the creative clusters in the capital Copenhagen. More so, in a related survey the CCI mapping of Lagos, Nigeria conducted by the British Council, Lagos in 1983, in collaboration with some researchers, found out the Nigerian creative industries continue to form economic expansion and sustenance for a large number of the population in the different sectors of the economy, in so doing creating national unity. They have been identified as the fastest drivers in the Nigerian/world economy (britishcouncil.org.ng, 2013). The survey showed that

Combined, the creative businesses surveyed contributed $=\mathrm{N}=2,547,300,490.26$ during the reference period with 61 per cent of the total GVA derived from the Film industry alone Fashion and Music contributed 26 and 13 per cent respectively. There was a steady rise in the GVA for both state and sector levels between 2010 and 2012.Employment Size/ Number of Businesses. A total of six thousand and sixty $(6,061)$ people are fully employed (p.8)

These figures indicate that the sector is a very lucrative area in the country's economic sector that the government has to pay attention to employment as well as for the export of products. In another instance, in 2017, in the UK alone, the DMCS contribution to the national economy stood at $3.6 \%$, which is $£ 250$ billion accounted for 14.2 of the national GDP (www.gov.uk,2017) and the industry alone is estimated to be worth over £92billion according to a 2017 statement by DMCS. These sectors, in 2015 netted about $£ 85$ billion. With the 2015 results; there was a remarkable rise in the performance. The Secretary of State for DMCS Karen Bradley regards the sector as one of the fastest-growing in the UK economy. (www.gov.uk,2017). In a related development, in the U.S. economy is 2015 , the CCI sector contributed $\$ 765$ billion to the national economy more than other sectors like warehousing, agriculture and transport according to the U.S. Bureau of Economic Analysis and the National Endowment for Arts. The arts sector alone raised about $4.3 \%$ of the national GDP, that sector also employs about 4.9 million workers. Also the CCI sector grew by $2.6 \%$ from 2012-2015 outperforming the entire sector. .This report clearly shows that the CCI sector is very paramount to the economy. In Nigeria, Vice President Osinbajo while launching The Dome, a recreational facility in Abuja, in May 2018 said that the creative industry in Nigeria has contributed 
about $\mathrm{N} 239$ billion, which stands for $2.3 \%$ of the national GDP in 2016 alone, indicating that the country is most likely to generate about $\$ 1$ billion from the CCI sector in 2020. (Agbakwuru, 2018).

At the global level, the CCI has contributed immensely to the development of the world economy. In 2018, the contribution stood at $\$ 2.250$ billion in revenue, making 3\% of world GDP. The highest earners in the ranking include television ( $\$ 477 \mathrm{bn})$, magazine and newspapers (\$354 billion) and the visual arts $(\$ 391 \mathrm{bn})$.In the same year, it also generated 29.5 million jobs, the top employers include: visual arts 96.73 million), books(3.6 million), and music 3.98 million) (Santiago, 2015) All these can be represented graphically for clear understanding.

This is a clear indication that the CCI sector that has generated and it is still generating more jobs in the world today. A look at the global GDP as per the contribution of CCI will make this point clear.

From the indications, creativity and innovation are now contributing in no small way to the growth of the economy of many nations, according to the Organization for Economic Cooperation and Development (OECD) survey. Countries are now developing CCI consistently to generate higher revenue and employment. The facts above indicate that the CCI has developed opportunities on a large scale and contributed to the growing world economies. It is obvious that the gain in this sector is controlled by the Asian countries followed by Europe and North America, while Africa and Latin America who, who are making an enormous gain, follow behind.

There is no question about Africa not doing well in CCI, it has tapped into that opportunity to put her creative products on the world stage through music, film, literature, and the creative arts, including antiques. A lot is being exported to Europe. There is also economic reawakening and consciousness in Africans to also consume locally made products. Nigeria's contribution to the world economy through the creative industries, especially in the film and, music cannot be ignored. The film industry, especially Nollywood is one of the largest employers in the country after agriculture and generates about $\$ 500 \mathrm{~m}-\$ 800 \mathrm{~m}$ annually employs a huge percentage of the population, directly engages about million people in full-time employment and about one million in indirect employment. (Hruby,2018) This directly implies that can develop an economic value chain between the government, entrepreneurs and the artists to create jobs contribute to the annual GDP growth. The industry directly employs 300,000 people and indirectly more than a million. The success of the Nollywood demonstrates how the creative economy can trigger a value chain between artists, entrepreneurs, distributors and support services to boost jobs and contribute to GDP growth. In the music and fashion sector, Nigeria is also not left behind in those CCI. Nigerian film and music brands are known all over the world. In 2015, according to Pricewaterhouse Coopers, an international auditing firm, music sales alone made over $\$ 56 \mathrm{~m}$ which may grow to $\$ 88$ million in the next three years (Smart -Abbey,2016). Music has become a cultural export for Nigeria as musicians like Dbanj, Tiwa Savage, Square, Burna Boy, and Flavour are known beyond the shores of Africa. Nigeria fashion is also fully represented in the world fashion centres like Paris, New York and London. As it stands today the CCI is a force to reckon with and can no longer be relegated to the background because they have their full impact on the economy, as they have been fully incorporated into the growth plan of the global north and south.

\subsubsection{Assessing Nigeria`s Position in the Global Space}

The local film industry is recognized globally, it has world-class movies with great themes and message that are acknowledged all over the world. Nigerian films are sold in most African countries and in most European centres (Opeyemi.2018)This is encouraged by the immediacy of globalization, which has filtered through almost all aspects of life and transformed the local economic system. Somehow this makes people to "Think global and act local". The exchange of culture through globalization has enabled the standardization of product and production, which has enabled the exchange of good at a quicker rate in any part of the world, between the global north and south. The exchange system caused the popularity of the Chinese, American and Indian films in the 1970s and 1980 's in Nigeria, which enabled this country to export their cultural goods through the portal of popular characters like Bruce Lee the icon of karate and Chinese Kun-fu(Polly,2018; Bowman ,2015; China highlights,2018) and also the popularity of American western cowboy movies. The Indian movies were also not left out. They pushed their culture to the world through their CCI. The Nigerian film industry was vacillating between these film cultures until in 1992 with the arrival of Kenneth Nnebue's Film "Living in Bondage" which broke the ice and established the Nigerian film culture. It was after this that the Nigerian movie attracted world attention and the attention of Nigerians were also diverted from a foreign culture, movies to the production and consumption of local movies. Thanks to globalization, the film industry ceased that moment to project the Nigerian film to the world and has been consistent since then. From another angle, globalization caused the dominance of the Nigerian movie stage strange movies that pushed an alien culture and this resulted in the denudation of the Nigerian film culture. This erosion was halted by the arrival of the Nollywood and its subsequent dominance of that industry up to this moment, 
though they're still vestiges of neo-colonialism in the industry where the storylines are lifted directly from the western movie culture. The Nigerian film industry should make a concerted effort through globalism to propagate Nigerian culture through films by establishing itself as part of the global film tradition. This opportunity should not be allowed to slip by as the film industry here is rated as the second biggest in the terms of production of films in the world. The film industry here has also been cavilled as low by world standard and that it lacks complex thematic content and are easily foreseeable as its story is always centred on ephemeral issues connected with mundane subjects like the casting of the villages in a bad light, juju, religious fundamentalism (Bornagainism), fighting over an inheritance amongst other transient matters that can easily be predicted. Cosequently, it has projected certain negative attributes like prostitution, fake living, male domination, suppression of women, among other vices(Opeyemi,2008). Because of these encumbrances, the film industry has not been able to produce any classic for the world as they continue to emulate the global north in film style and structure. With globalization, the film industry should be able to use the channel to project internationally recognized movies that portray evil in the Nigeria culture with a universal appeal by tapping into the globalization concept. Aside from the scathing criticism of the pitfall of the local film industry, that sector of the CCI has attracted the interest of scholars internationally fascinated by the successes of that sector. This interest has put that sector on the international pedestal and encouraged a rethinking among the producers as they now fight to be seen globally by endeavouring to upgrade their films to international standard. This can only be done through globalization, where everyone competes in a global stage and the best wins. The stereotypical assumption for the Nigerian film as mentioned earlier is cast on the negative side as most films are folkloric in style. The industry has managed to be global, it cannot afford to recline, it must tell a great story that will project The African and Nigerian culture as the British have done with a James Bond 007 movie, which has portrayed their culture for generations. Nigeria must project this culture playing in the global theatre through globalization, which trying to influence the world from a local stage. The local film content must be related to the tradition that will be projected internationally. This must be done because the prevailing social tradition and the production of films are synonymous, so whatever the film industry projects to the world would be assumed to be the reality because they are intricately bound, although some of these images may not portray the reality.

The Nigerian identity is vital in the move to have a position in the global space. Such identity must stand for its philosophy, no matter the challenges they may face consequences on socio-political social challenges. It must be shown in the film culture that Nigerians are determined to fight on and these messages portrayed to the world through the normal channels of film and the media, thereby pushing it as a handle for cultural diplomacy and globalization of art, music, and literature which represent the entirety of culture. This positive image should be projected in the Nigerian movies and projected to the world as the American, and the Indians have been able to do. The American notwithstanding the imperfections in their system, have been able to push the elusive "American Dream" and imposed it on the world as something to emulate. In India despite the challenges of poverty, discrimination, and religious problems, have been able to impose their culture on the world through the movie. These two nations have sacrificed a lot through films to impose their culture on the world. The Nigerian film industry should fight assiduously to project the image of the country positively though the movies and must fight to project cultural norm that it should be identified with instead of projecting the nation in a negative light that has failed to protect the nation cultural ideology to attract positive attention to the country. Like the Americans, Chinese and Indians who have used movies to project their image, the Nigerian film industry should apply the same methods to attract world attention through the CCI. This can only be achieved through the global projection of the local culture.

In consideration of the above, it has become important that the film industry reposition itself in the universal space by projecting the positive angles of the Nigerian culture in the projection of Nigerian image to attract foreign attention. This because there is no challenge that the Nigerian film industry is dynamic and has put the country in the global space of CCI. With its vast potential, it may not be easy to ignore the country in the production of cultural products. But due to fragmentation in the industry, the paucity of political leadership, the country's position in the global space is now threatened. If these internal challenges are corrected, Nigeria will take its correct place globally as a major player in the universal film industry.

\subsubsection{Nigeria Music Industry in the Global Space}

The Nigerian music industry is as varied as the 350 ethnic groups in the country. Each group is related to a particular type of song, from the Atlantic to the fringes of the north, it is a different sound and style. The precontact music exudes undiluted originality that has originated from the peoples' ancient culture. There is almost music for every social context, life, death, birth, work and many more. From this diversified music culture, many 
categories of music have evolved, but this paper will explain five types. First, there is the traditional non commercial music that is played and danced during major ceremonies. This type is based on the culture of the people of a particular environment and it is played at a particular time of the year or during a special ceremony. In Igbo land, this can be during the new yam festival, owu (Masquerade) seasons, which usually comes after the planting period. This type of music is not commercially oriented. Second, there is the folkloric music; it accompanies folktales, stories, anecdotes, legends, and myths. Third, there is also another esoteric variation that accompanies spiritual activities. This usually is known to the people who belong to a particular ordination, or the priesthood. This type of song is not for public consumption of the unintended group as they are used mostly for sacrifices and initiations. The third category is the traditional contemporary music which is rendered in local languages but influences western culture and traditions, this is mostly composed of western instruments. This type is commercially oriented and they can be hired to play in public or private ceremonies for a fee. The next is the western type of music which has all the vestiges of westernization and it is the song in the English Language where the musicians try to imitate their western counterparts in style and performance, though at times diluted with African culture to create a variety. This modern music is adapted to western tradition, equipment and messages. It is either delivered in the real English language or pidgin English and at times laced with Nigerian languages. Most Nigeria songs draw inspiration from these genres and this has made them evident in the global space.

From the years past, Nigerian music has captured global attention by migrating to the global space. From the traditional Atilogu dancers in Igbo land that toured the European capitals and America in the 1960s and 1970s to the celebrated music personalities like Fela Anikulopo Kuti, Ebenezer Obey, King Sunny Ade, Oriental brothers Sony Okosun and recently Whizkid, D’Banj Flavour, Tekno, Omowunmi, just to mention but a few. They all evolved locally before they made it to the international arena. In the diaspora, there are also Nigerian musicians making waves and promoting the Nigerian consciousness and culture like Sade Adu, a British born Nigerian songster and Seal, the United States-based Nigerian singer(Ugbobude,2016). These people are cultural ambassador selling the image of the country globally. The Nigerian music industry has developed rapidly, locally and internationally to the extent that Nigerians now prefer local music to the foreign ones. In consonance with this fact, Adedeji(2016), maintains that Nigeria has an animated music institution that has come to designate her richness and culture, and with the years gone by, this has transformed to global acknowledgement. As was not the case in the past years, the Nigerian music now to a large extent dominate the airwaves in Nigeria and Africa (Ngomba,2015) and has also made an impact in the rest of the world through media devices like and YouTube and Apple Music and internet radio devices like radio garden, they have become ubiquitous in the global space. As at August 2018, top five Nigerian songsters with the highest views on YouTube include Yemi Alade (Jonny) 93 million, Psquare(Personally) 84 million, Davido (Fall) 79 million, Tekno (Pana) 77 million and Korede Bello (Do like that) 71million.(www.nairaland.com,2018). This popularity has also attracted the attention of foreigners who want to do business in the burgeoning music industry in Nigeria Some have set up companies to tap into this sector and have signed agreements with some Nigerian musician This is in addition to the indigenous music companies that are in the country. (nigeriafinder.com,2018) Some of these companies have signed an agreement to make Nigerian music to be available to the global audience. Some foreign musicians have made their presence known in Nigeria and they come here to play songs and entertain Nigerians. A practical example is the defunct Thisday Music Festival in the 1990s, sponsored by Nduka Obaigbena, the owner of Thisday Newspapers, it brought to Nigeria to the global spot as the festival also featured Nigerian stars playing alongside intentional musicians. According to (Molokwu, 2016)

The superstars included Beyonce Knowles, Shawn Corey Carter, popularly known as Jay-Z, Snoop Dog, Missy Elliott, Busta Rhymes, and Ciara; King Sunny Ade, 2Face Idibia, MajekFashek, D’ Banj, Lagbaja, Weird MC, Dare Art Alade. It was billed as the biggest music festival in Nigeria's entertainment history(P.2)

Through this collaboration, Nigerian culture was projected into the global space through music. Nigerian music has always won many global awards and recognition outside this shore. As at 2016, apart from winning most of the African music awards, seven Nigerian musicians have been nominated for four Grammy Awards, one of the biggest music awards on earth. They include King Sunny Ade,1983 nominated under folk and ethnic music category, Sade Adu was nominated record nine times between 1986-2013 and she won four times, Femi Kuti was nominated four times, 2003,2010,2012 and 2013, he has never won. Seal, a popular Nigerian musician in the diaspora has won four Grammy awards and has been nominated several times.(Obiora ,2017).In 2018, popular American singers like Ciara and Drake signed an agreement with a Nigerian songster, Tekno to collaborate in their songs(Abang -Adoga, 2018). Many more Nigerians are involved in the production of music globally. Okoroji (2014) summarizes the impact that Nigerian music has made globally

Let the truth be told: Today, at home, across the continent and indeed in most parts of the world, music created by 
young Nigerians has become dominant. To put it simply, Nigerian musicians have taken the world by storm. They are on top of their game. This revolution, which should bring a lot of pride to our nation has not happened as a result of any serious national planning or contribution from the state. It is the product of individual efforts and the never-say-die spirit of many young Nigerians and a few people who believe in them (p.2)

Nigerian music has permeated the global space, but it will take a greater effort to remain in the topmost position.

\subsection{The Challenges of Nigerian Film and Music Industry in The Global Space}

\subsubsection{Government Policy}

Until recent history, the Nigerian government has no clear cut policy on the development of the movie industry. They have neglected the creative potential of this CCI sector for a very long time. This is at variance with the development of the film and music industry in other parts of the world where the government and private individual are major players in that sector of the economy which has brought these countries to the global stage. In Nigeria, people consider the movie industry from the perspective of an economic venture only hence the rush to produce for money. Care is taken not to produce a standard movie that will project culture and creativity to the world. This attitude has etched itself on the mind of Nigerians because of this long neglect by the government, which has made the film and music sectors to fall into the hands of charlatans. If this erroneous conception is not corrected, the position of Nigeria in the global space in the film and music production may slip and Nigeria will lose a position in the global export of culture. Some of these challenges include: There seems to be no clear-cut and the little one in place are not being implemented government policy on the film and music industry apart from the normal endowment that is inconsistent. There no policy direction of disbursement and accountability of the money donated by the government, which soon disappears under government bureaucracy for example the federal government under President Jonathan released the sum of $\$ 200 \mathrm{~m}$ in grants to the film industry. In March 2011 there was another donation of \$ii5m under the aegis of "Act Nollywood" (Hammed ,2018). Some films like Half the Yellow Sun was produced by some of these endowments by the government. Though the government has tried to project the CCI by doling out money there had been no effort to institute a strong film and music philosophy that will project the Nigerian of CCI in the global space.

\subsubsection{Piracy}

The numerous global laurel and appeal on Nigerian music notwithstanding, the Nigerian music industry just like the film, faces a myriad of challenges. Accepted that the Nigeria is the center of African music and her fame has been noted in the globe, but many challenges are hibernating under this global glory, many people who are connected in the industry have always pointed these out, noting that if these are not handled correctly may founder at the music industry. The number challenge of the music industry in Nigeria is the exit of multinational recording companies, this fractured the process of music production. This movement was facilitated by the devaluation of the Naira and the dominance of piracy that never allowed music companies to recoup their investment. The situation encouraged piracy and the rape of intellectual property (Adedeji, 2016). This debilitating piracy has been left unchecked by the government that it has taken root in the Nigerian economic system. Piracy exists in other countries, but it's not left unchecked. In Nigeria, it is done boldly and openly. It is blatantly done by individuals, broadcast station, even by corporate bodies use music for advertisement without paying a royalty to the copyright owners. Many radio station plays music without royalty to the owners. The Nigerian Copyright Commission) NCC and Nigerian Broadcasting Commission (NBC) including the other regulatory bodies are not perturbed by this regardless of of the numerous agreements(Okoroji,2014). Also, in the movie industry. This is a major challenge in the Nigerian film industry today as investors in the film industry are unable to recoup their investment on the films produced due to unregulated piracy in that sector. Once a movie is produced or even at times before the official release, pirated copies appear in the market in different parts of the country (Hammed, 2018). A recent study by the $\mathrm{BBC}$ revealed that about $90 \%$ of the movies produced in Nigeria are pirated, buyers go for them because they are cheaper (www.bbc.co.uk,2015). Apart from physical piracy, most of the films are released online without prior approval by the producers. According to Akpotaire, (2013) in the terms of distribution in the global space, the distribution has been encouraging; on the other hand, it has also led to the reduction of economic benefits for all those involved in the production of the movie due to piracy and unauthorized release and distribution of films. This seems to be another new challenge on the old issues, the nascent online piracy. 


\subsubsection{Factionalization}

From the film Ficho, the first colour film produced in Nigeria before independence to the present time, the Nigerian film industry are factionalized along ethnic and professional lines, just like the Nigerian political landscape (Izuzu,2017). Mediocrity, envy, and professional arrogance have plagued the film industry, it's so acute that it is now threatening to remove Nigeria from global relevance. It has now evolved from the normal Nollywood to innumerable faction, all working at cross purposes. Some of the factions include: the old Nollywood, made of the old faces who stated the home movies, The New Nollywood made up of the new talent who are usually regarded as upstarts, there is also the Kannywwod established in 2012 by a crop of Hausa actors, yet another is the Callywood based in the Tinapa studios in Calabar believed to have been created in 2016. It will be worthwhile to mention that there a Yoruba film faction who antagonize Nollywood based on the etymology of the film industry in Nigeria. Under these factions, there are also sub-factions like the Asaba movie actors, Edo filmmakers, the Enugu film actors and host of others who does not agree as a matter of deliberate policy(Izuzu,2017). With all these factionalizations in the industry it will be challenging for movies to find a niche in the global space because all these factions are contesting for supremacy, they are dissipated on irrelevancies and the tussle for leadership will never enable them to present a common front in the global space( Hammed, 2018). In the music sector, there has been fictionalization. In the Copyright Society of Nigeria, the society that should be collecting royalties for Nigerian songs, there is a fictionalization in leadership. This section of the CCI is also split between ethnic and religious lines. There is the Islamic Musicians Association of Nigeria (ISMAN), which has another splinter group, Professional Islamic musicians of Nigeria (PISMAN),(Ajagunna,2015).

\subsubsection{Lack of Talent}

In terms of actors and the production of Nigerian movies, there are challenges. In terms of talent and creativity, this is noticeable in some substandard films which exhibit a lack of a professional touch by the individuals involved in the film production. The film industry in Nigeria has never lacked talent because of the likes of Hubert Ogunde, Baba Sala, Pete Edochie, Genevive Nnaji among other battery of professionals, acutely talented actors and producers. The film industry is also a conglomeration of interlopers who do not want to learn the ropes, consequently, they have no clue of what the film industry is all about. Some films are so badly directed that it is so distant from the reality of our experience. Nigerian film and music industry has faced many challenges, but despite all its imperfections, it is one of the country's most vibrant export brands globally. It is steeped in dynamism and colour that has attracted comments from all over the world. Through film Nollywood has become a name to reckon with in the global space today and what can be described as the heart of the film industry in Africa. It is almost not practical to disentangle the current situation in Nigeria from the global image portrayed in the films (Abubakar, 2018). Likewise, in the music industry; most practitioners do not understand the intricacies of music. This has led to unprofessional conduct by the practitioners. This lack of consciousness has led some of them to sign dubious contracts with producers that they end up regretting

\subsection{Conclusion}

It is inevitable that the globalization of the creative and the cultural sector is unavoidable and that it will advance at the same rate as science and technology. With the shrinking of culture due to the new media, more countries will stand to benefit from CCI. Nigeria must endeavour to sustain its enviable position in the global space to be to get the gains that will come from that sector shortly, especially now that the country's debt profile has become a source of apprehension for officials and improvement consultants, as the country`s debt service-to-revenue ratio stands at 60 per cent, which is expected to worsen due to falling oil revenue and COVID-19 crisis. The Nigerian film and music industries have inevitably influenced global culture and collaboration and the position of the country is quite relevant because through the CCI, Nigeria has also been able to export its culture to the world and at the same time absorbed a lot from the world which has somehow resulted in the glocalization of culture as some international film and music concerns now crave for Nigerian content to blend with their own to produce a hybrid of culture. Nigeria is noticeable as this paper has indicated, however, there are structural issues that if not handled with tact may cause Nigeria to lose global rating. Most of them are listed in the paper. Therefore, there is an urgent need to tackle theses problem to sustain Nigeria in that global pedestal and this can be done through adequate support for the CCI. 


\subsection{Arrears for Future Research}

Many areas of the text may be used for future research to advance Nigeria's role in the global creative and cultural industries, but attention will be paid to a few areas of concern: digital media should be deployed to promote the current growth of the creative and cultural industries in Nigeria. Second, researchers should take advantage of Nigeria's willingness to strive for a hybrid culture by globalization. Third, attention should be given to ways of maintaining the Nigerian music and film industries globally through a convenient governmental system. These areas, if properly utilized, will open a new view in the global marketing of Nigerian content.

\section{References}

Abang A.(2018).Popular Nigerian musicians.Retrieved from www.today ng

Abubakar, M.M.(2018)Globalization and the creative /cultural industries: An assessment of Nigeria's position in the global space. Speciality Journal of Humanities and Cultural Studies 3.(1),10-17.

Adadeji, W.(2016).The Nigerian music industry: Challenges., prospect and possibilities.Retrieved from www.researchgate.net

Agbakwuru, J.(2018).Nigeria GDP to reap \$1bn from entertainment, creative sector by 2020-FG. Retrieved from www.vanguardngr.com

Ajagunna,T.(2015).Third faction emerges in islamic music industry.Retrieved from www.thenet.ng

Apkotaire .U (2013)Nigeria's thriving music industry: A walk down Nollywood lane.retrieved from www.nlipw.com

Bowman, P.(2017) Bruce Lee: Cult (Film) icon. Retrieved from researcgate.net.

Bright, J.(2015) Meet nollywood, the second-largest movie industry in the world. Retrieved from

British Council(2013). Mapping of Nigeria creative industries: Report of Lagos pilot study.Lagos: British Council.

Bruce Lee (1940 - 1973) (2018). Famous Chinese Kung $\mathrm{Fu}$ Actors.Retrieved from https://www.chinahighlights.com

Creative Edge. (2013). Exploring the Extent and Impact of the Creative Economy in Europe's Rural Regions.Retrieved from www.creative-edge.eu

Dandaura, E.(2013).Mapping of Nigeria Creative industries: Report of Lagos pilot study. Retrieved from www.researchgate.net

Eleanya,F,(2020).Nigeria's creative industry can bridge unemployment gap if funded.Retrieved from businessday.ng

Florida, R.(2018). The rise of the rural creative industry.Retrieved from www.businessinsider.com

Galloway, S \& Dunlop, S. (2006). Deconstructing the creative industries. Gerlach \& Handke

(Eds).Cultural industries: The British experience in international perspective. Retrieved from http://www.edoc.hu-berlin.de

Garnham, N.(2005). From cultural to creative industries. International Journal of Cultural Policy. 11 (1).1629.

Giddens, A.(2018).Consequences of modernity. Stanford: Stanford University Press.

Hammed,F.(2018) 10 challenges facing Nigeria music industry.Retrieved from https://infoguidenigeria.com/nigerian-film-industry/

Hesmondhalgh, D.(2008).Cultural and creative industry in Bennet, T\& Frow, F $\quad$ (Eds) 1-19.Handbook of cultural analysis. Oxford: Blackwell.

Higgs, P.\& Cunningham, S. (2008).Creative Industries Mapping: Where have we come from and where are we going?, Creative Industries Journal.1 (1), pp. 7-30.

Hruby,A.(2018).Tap creative industries to boost Africa's economic growth.Retrieved from https://www.ft.com

http://fortune.com/2015

Izuzu,C.(2017).Evolution of Nigerian film industry.Retrieved from www.pulse.ng 
Lefebvre, H. (1991) .The production of space. Oxford: Blackwell.

Magaji, H. (2017).FG reiterates support for creative industry. Retrieved from https://www.financialwatchngr.com

Molokwu ,A.J.(2016).Nigerian Music.Retrieved from www.saharareporters.com

Ngomba,J. (2015).Nigerian music and the African continent.Retrieved from www.pulse.ng

Northrop ,D.(n.d ) Globalization in historical perspective.Retrieved from www.eolss.net/Sample

O'Connor, J.(1999).The definition of cultural industries.Retrieved from http://www.mipe.mmu.ac.uk/iciss/reports/define.pdf

Obiora,E.(2017).Ten famous Nigerian musicians.Retrieved from https://buzznigeria.com

Okoroji,T.(2014,September).The state of Nigerian music industry.Paper presented at the coscon conference in Lagos.

Polly ,M. (2017).Bruce Lee: Life of an icon. Retrieved from https://the1a.org

Publications.

Rourke,K.H.\& Williams ,J.G.(2002)When Did Globalization Begin? European Review of Economic History, Cambridge University Press. 6(01), pages 23-50.

Santiago (2015). What is creativity worth to the world economy?Retrieved from https://www.weforum.org/agenda/2015

Shefffield ,J.C.(2010).Globalization yesterday, today and tomorrow.Litchfield:Emergent

Smart-Abbey,N.A.(2016). Nigeria's music industry, an economic backbone in need of protection. Retrieved from http://www.africanews.com/2016/

Soja, E. (1999).Thirdspace: Journey to Los Angeles and other real-and-imagined places. Oxford: Blackwell Publishers.

Torres,C\& Seters,J.C.(2016).Overview of trade and barriers to trade in West Africa.Retrieved from http//:www.tralac.org/images/doc

Valdivieso ,O.J.Z.(2016)Infinity opportunities in the inclusive development of Santander.(n.p).

Yahya,Mohamed.(2020).Nigerian Creative sector steps out for UNDP.Retrieved from www.ng.undp.org 


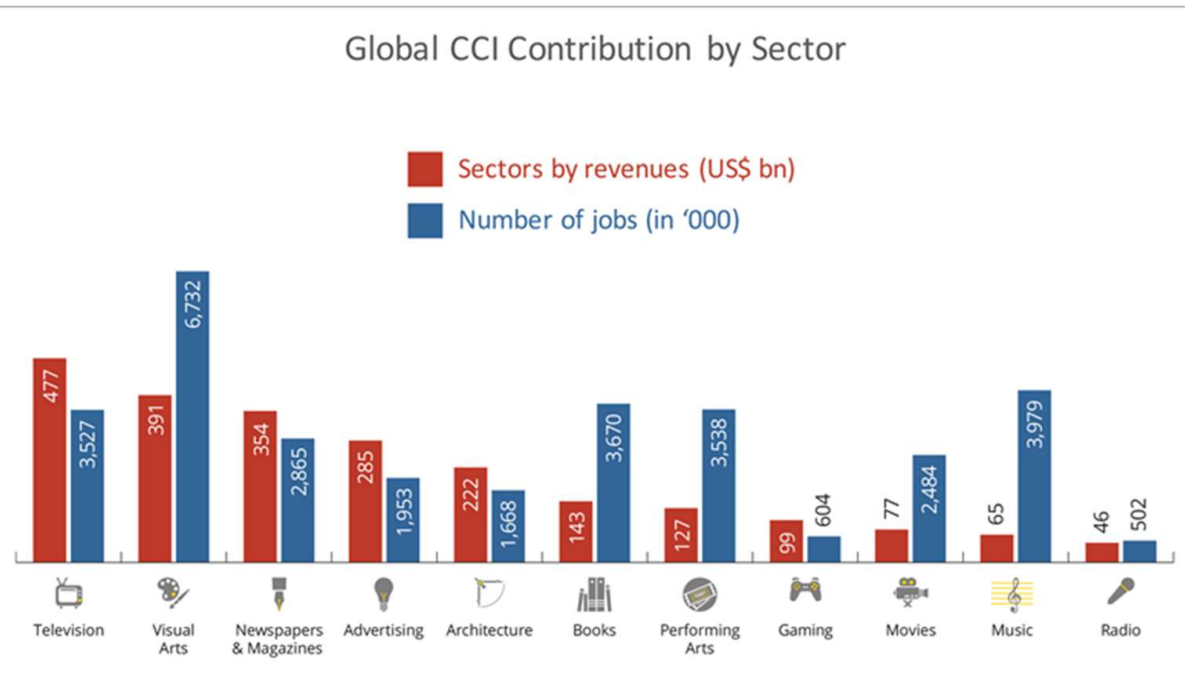

Source: EY, December 2015

Fig. 1 The Global Creative Economy Is Big Business.Retrieved from Google.com

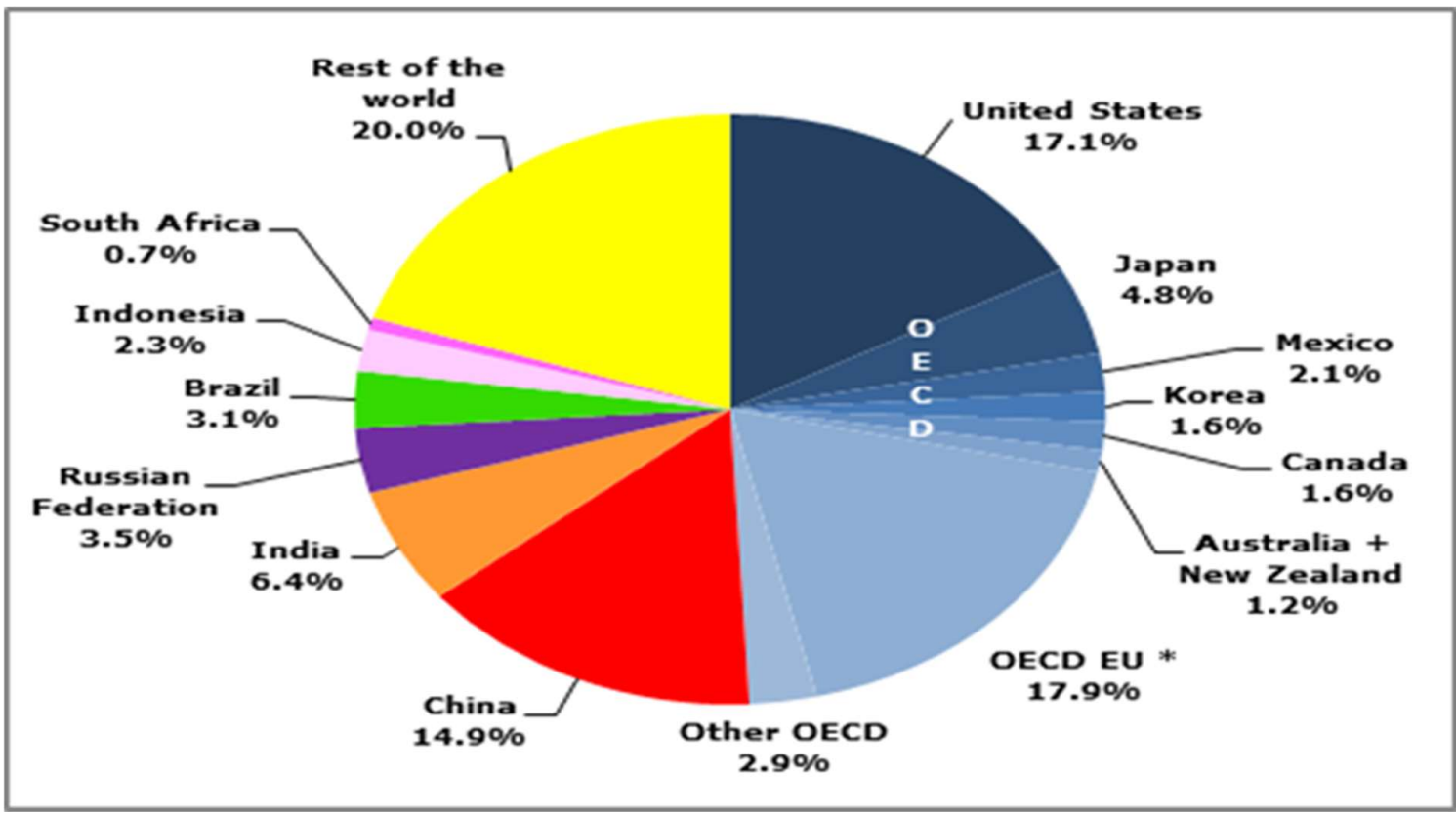

Fig. 2. www.oecd.org.contribution CCI to world economy.Retrieved from Google.com 